\title{
Head Room Supervision to Completeness of Note Nursing Care Documentation
}

\author{
Muhamad Andika Sasmita Saputra \\ Master of Nursing, Faculty of Nursing, Andalas University \\ Padang, West Sumatera, Indonesia
}

\begin{abstract}
Nurse's disobedience in documenting the nursing care is still a problem in various hospitals in Indonesia including Palembang, which impacting on quality of nursing services provided. This research aims to know relationship the role of supervising and mentoring head room with nurses in carrying out compliance documentation of nursing care in Islamic Hospital Palembang. This research used the approach of cross sectional with 63 samples of nurses with their nursing care documentation. Proportionate sample retrieval technique of random sampling. Analysis of univariate data using independent variable mean further categorized. The dependent variable was analyzed using standard $80 \%$. Analysis bivariate test using chi square. The results showed no relationship with compliance supervised the head nurse in the documentation of the completeness of the records document of nursing care. Expected role of mentoring the head room can be optimized with the head of the room gives the opportunity to add the knowledge related nursing care through training.
\end{abstract}

Keywords:- Supervision, Documentation, Nursing Care.

\section{INTRODUCTION}

Documenting the nursing care is an important part in the granting of medical services in hospitals, and each implementation is not far from five nursing process that includes assessment, diagnosis, intervention, implementation, and evaluation. The fifth application this process is still a problem in various hospitals in Indonesia. The last few years research results reported are still many disobedience in documenting the nursing care of the nurses as study conducted in ICU-ICCU Gambiran Hospital Kediri East Java 57.9\%, in Inpatient Ambarawa Hospital 53.84\%, and in GMIM Pancaran Kasih Hospital Manado 65.78\% [13].

Nurse's disobedience in documenting care nursing can lead to malpractice and nursing actions duplication is done. According to the concept of nursing care of one of the purposes of documenting is as a communication tool, the mechanism is responsible lawsuit and as the audit services of nursing [4-6]. The more wayward nurses document nursing care will be the higher the risk of the occurrence of errors in administering nursing care, the less evidence of the responsibility the answers and on nurses. In an effort to avoid this then, the role of a Manager in the management of nursing process documentation is very important, especially related to the nurse's disobedience.

\author{
Yulastri Arif, Vetty Priscilla \\ Lecturer of Faculty of Nursing, Andalas University \\ Padang, West Sumatera, Indonesia
}

Defiant nurses are key failures in the documentation of nursing care [7,8]. Disobedience is an evil entity, either deliberately or whether someone against a plan or rules. Various studies about nurse disobedience in documenting the care of nursing has done. The results of such research report there are four factors that inhibit adherence of nurses in documenting the care of nursing, namely: (1) do not share the amount of power the nurse with an existing job, (2) the format is too long, (3) low the motivation of nurses documented, and (4) knowledge of nurses is not good [911]. In addition to the research results, some performance theories to explain the factors that affect the performance of the nurses, including performance in documenting care nursing.

Many theories of performance that is used in the fields of nursing, one of which is a theory of performance expressed Gibson year 1987. Gibson performance according to the concept, there are three main variables that affect the performance of a person that is: (1) individual variables, (2) variable organization and (3) the psychological variables. Variables include individual capabilities, skills, educational background, and work experience in documenting the nursing care of the nurses. While the organizational variables include resources that support the implementation of the disclosure requirements, the leadership of the head of the room in supervising and mentoring implementation documentation of nursing care, rewards or reward, the structure of the work with regard to the process of documentation and design work [12].

Head room as nursing managers must carry out supervisory functions in managing documentation of nursing care. One form of Staff is to do supervising. Findings the ability of supervising head room is a good opportunity to improve the completeness of the documentation of nursing care three times better [13-15]. It can be interpreted that the supervising Chamber head's ability to contribute positively towards the nursing complement documentation submission.

Supervising is one of the efforts to reduce noncompliance of nurses in documenting care nursing. Based on the concept of supervision are actuating at step as one of the efforts in maintaining and controlling all activities that are underway in order to be carried out according to plan [16]. The contribution of a head room in supervision will improve the quality of nursing care of documentation because it will directly visible barriers and problems in its implementation $[17,18]$. In practice, however, a supervisor must have expertise. 
The head of the room as a supervisor must have some functions and roles. Functions and roles that include: (1) creating a work plan, (2) control the work, (3) solve problems, (4) give feedback on performance, train staff (5), (6) motivator, (7) manage time, (8) personal communicator, (9) manage the self, (10) create a workplace, (11), (12) counselor communicators in formal interactions, and (13) of voters a referral [19-21]. By understanding this concept will be the added value of a head of the Chamber of doing the supervising.

Nursing activity supervision is already applied in foreign countries. Some developed countries such as America, Europe, and Australia has been conducting these activities are structured and systematic [22-24]. This indicates that these countries have made routine activities as supervision in nursing. Through the existence of supervision will then very likely can minimize the numbers of nurses disobedience in documenting care nursing.

\section{METHOD}

\section{A. Research design}

This research is a quantitative research using the method of correlation through cross sectional approach. This research was conducted on nurses room Inpatient Islamic Hospital Palembang.

\section{B. Sample Research}

The sample of this research is the 63 people with criteria of inclusion: (1) a nurse who does documentation of new patients, (2) are willing to be respondents and ekslusi criteria: (1) a nurse who is currently on leave, (2) Nurses who are doing the task of learning, (3) Implementing intensive at nurses room.

\section{Research Ethics}

Before collecting the data, researchers must first take the test of ethical practice in public hospitals the Center Muhammad Hoesin and Faculty of medicine University of Sriwijaya Palembang and declare this research worth doing in place of research with the number certificate of 72/kepkrsmhfkunsri/2018.

\section{RESULT}

\begin{tabular}{lll}
\hline Variable & $\mathrm{f}$ & $\%$ \\
\hline Role of Supervising Head Nurse & & \\
Good & 39 & 61,90 \\
Less Good & 24 & 38,10 \\
& & \\
Adherence of Nurse in Nursing & & \\
Care Of Record Completeness & 29 & 46,03 \\
Adherence & 34 & 53,97 \\
Not adherence &
\end{tabular}

Table 1. Frequency distribution Role Supervising Compliance and a Head Nurse in the Nursing care of Record Completeness $(n=63)$

Table 1 above shows that over some number of nurses $(61.90 \%)$ perceives the role of supervising head room in the category, and the majority of nurses implementing (53.97\%) did not comply in writing a note of the complete nursing care.

\begin{tabular}{|c|c|c|c|c|c|c|c|}
\hline \multirow{3}{*}{$\begin{array}{l}\text { Role Supervising Head } \\
\text { Nurse }\end{array}$} & \multicolumn{4}{|c|}{$\begin{array}{l}\text { Adherence Nurse in Nursing Care Of Record } \\
\text { Completeness }\end{array}$} & \multirow{2}{*}{\multicolumn{2}{|c|}{ Total }} & \multirow{3}{*}{$\mathrm{p}$ value } \\
\hline & \multicolumn{2}{|l|}{ Adherence } & \multicolumn{2}{|c|}{ Not adherence } & & & \\
\hline & $\mathrm{N}$ & $\%$ & $\mathrm{n}$ & $\%$ & $\mathrm{n}$ & $\%$ & \\
\hline Good & 16 & 66,67 & 8 & 33,33 & 24 & 100 & 0018 \\
\hline Less good & 13 & 33,33 & 26 & 66,67 & 39 & 100 & 0,018 \\
\hline Total & 29 & 46,03 & 34 & 53,97 & 63 & 100 & \\
\hline
\end{tabular}

Table 2. The results of statistical tests the role of Supervising Compliance with Head Nurse Implementers in the completeness of the records of Nursing Care $(n=63)$

Table 2 above shows that 39 people from implementing the nurse perceives the role of supervising head room in the category of less well obtained $(66.67 \%)$ nurses wayward implementers to write a record of the complete nursing care. Of the 24 people the nurse perceives the role of supervising implementers of head room in the category either obtained $(66.67 \%)$ managing wayward nurses to nursing records writing orphanage. Based on the data above, it can be concluded that there is a relationship role of supervising compliance with the head nurse in the nursing care of write notes in full.

\section{DISCUSSION}

The results of research conducted at Islamic Hospital Palembang showed that more than some number of nurses $(61.90 \%)$ perceives the role of supervising head room in the category, and the majority of nurses implementing (53.97\%) did not comply in write a note of the complete nursing care. The results of several hospitals in Indonesia are also uncovering non-compliance of nurses in the nursing care of documentation like in Inpatient Pariaman Hospital (60.46\%), in Inpatient Ambarawa Hospital (53.84\%), GMIM Pancaran Kasih Hospital Manado (65.78\%) [25,2,3]. Studying of some research on nurse disobedience in the Inpatient Islamic Hospital Palembang turned out to be higher compared to other type hospitals in Indonesia. Noncompliance in the disclosure requirements will impact bad for nurses and patients.

The impact of bad nurse disobedience in documentation of nursing care of potentially causing the occurrence of malpractice, the absence of legal protection, and the occurrence of repeat nursing actions. Nursing care 
of documentation used as the identifier tool complaints and illnesses experienced by the patient as well as the action to be performed [26]. So when the nurse didn't do well then it is likely a documentation error in the action also will be even greater.

Part of the nursing process is the completeness of the records document the care nursing. More than half the nurses exercise of obedient in carrying out documentation completeness note nursing care in Islamic Hospital Palembang $(53.97 \%)$, Ibnu Sina room get the highest adherence $(100 \%)$. Results of the study at the hospital same of type obediently at the Dr. Moewardi Hospital Surakarta (43.8\%), in Inpatient Pariaman Hospital (33.80\%), in Islamic Hospital Kendal $(83,6 \%)$ [27,25,28]. Through the above research can be analyzed that nurses in carrying out documentation of the completeness of the records document the care of nursing in the Islamic Hospital Palembang still low if compared with hospitals that achieve standards of $80 \%$ than the same of hospital. The results of the observation assessment aspects; the recording was done in accordance with actions implemented (23.80\%), the recording is written in clear, concise terms, raw and true $(19,04 \%)$, every action lists the names of nurse/initial is clear, and did date action (36.50\%) nursing notes, files are stored in accordance with the applicable provisions $(93,65 \%)$. Files are stored should be based on the prevailing order in Islamic Hospital Palembang include CPPT (Evaluation), assessment, diagnosis, intervention, and implementation.

Include your name/initial, the date and time the action performed is essential for nurses. Documentation nursing legal aspects into orphanages, proof of liability and responsibility on the legal protection of nursing resources in performing the service of patients [29]. Nurses are often forgotten and impressed neglects to include name/initial, dates and hours after doing the action [30]. The nurse does not list the name/initial, date and hour after performing actions will make confused his colleagues [31]. Thus the impact of nurses who do not list the name/initial, date and hour after performing actions can potentially recurring actions and not the occurrence knew who was doing the action so there could be a material accountability.

Compliance of nurses in the nursing care of the documenting of SPO made by the hospital. Nursing care of SPO is a reference for nurses which contains details of tasks, guidelines or directives to carry out documentation of nursing care $[32,33]$. Therefore the SPO is important so that the documentation of nursing care can run well. Unfortunately the available research SPO still in revision and has not been socialized. In addition to the SPO need into consideration also form facility nursing care provided in room [9,34], if the form is not available in the room then it will inhibit the implementation of the process of nursing. So far researchers observe form provided in adequate and not experiencing a shortage of supplies, nursing care in the form of a room is kept at the place of storage and cabinets are arranged by the name of the medical diagnosis, but very pity the nurses still don't use it optimally. This is evidenced by the many no finds form diagnosis intervention in patient status.

From all the above findings, the hospital can review the exercise of documenting the care of internal audit with nursing documentation. The audit itself can be done by the audit team as well as appointing a particular person or directly carried out by the Committee of nursing. The existence of the audit will be seen to taking nursing shortage that occurred in field in order to prevent any damage that may be experienced in the future as well as the implementation of documentation while maintaining efficient and effective nursing care that affect the quality of services, satisfaction is also patient safety $[35,36]$.

In addition to the audit, the head of the room will also need to pay attention to the method of assignment is executed. Based on the results of the interview on the stage of the initial data retrieval methods used in the inpatient room is the team method. Leader certainly has the task to supervise and execute the implementation documentation of nursing care is done, because the head is leader room. So good head of team nor members must understand and communicate about job description in order for the execution of documentation of nursing care can run well $[37,38]$. But the head of the room as the manager is still required in the conduct of supervising and mentoring nurses implementers in the hospitalization.

In the implementation of the nursing care of the team, leader as professionals acting as nursing care assessment, determine diagnosis, intervention, and assign task implementation to managing nurses, then perform evaluation [39]. Based on the observations in the field every nurses fill out the form documentation of nursing care. It is certainly contrary to the above theory, so the head room as managers need to reaffirm the role of each team and its function.

To see the execution of documentation it is necessary supervision actions. Based on the results of research conducted at the Islamic Hospital Palembang obtained that 39 people from the nurse perceives the role of supervising implementers of head room in the category of less well obtained $(66.67 \%)$ of nurses implementing not obedient to write notes of nursing care. Of the 24 people the nurse perceives the role of supervising implementers of head room in the category either obtained $(66.67 \%)$ managing wayward nurses to nursing records writing orphanage. Based on the data above, it can be concluded that there is a relationship role of supervising compliance with the head nurse in the nursing care of write notes in full.

This unfavourable perception obtained from implementing nurse answers on questionnaires. The role of supervising the head creates less good indoor work plan $(55.56 \%)$, out of the question, "the head of the room makes the supervision implementation plan documentation of nursing care" more than half of nurses implementing perceives less well $(53,97 \%)$, whereas the question "the head of the room taking notes about the duties and obligations of nurses should be carried out" less than half of 
nurses implementing perceives less well (25.40\%). As a Manager, the head of the room must be able to coordinate the work done by nurses implementers [40]. Thus the head of the room need to optimize returns managing nurses work plan in the documentation of nursing care.

One of the steps that can be done in the optimize plan of work is the regulation of method in the documentation of nursing care. Based on the results of the interview with the head of the installation at the time of initial research, data retrieval method assignment which is applied in the Inpatient Islamic Hospital Palembang is the team method. The methods of the team led by professional nurses [37]. Duties and responsibilities of each Member head of team should detailed and clear.

Head of team is the extension of the hands of head room in the implementation and documentation of nursing care. Therefore, the head of the room should control the work performed by head of team. The results showed that more than half of nurses implementing perceives the role of supervising head room in the control implementation documentation of nursing care of less well (50.79\%), especially in terms of evaluating the documenting the nursing process $(50.80 \%)$. To achieve optimal nursing care services thus needs to be done in carrying out nursing performance evaluation documentation of nursing care [41]. Through the existence of an evaluation from the head of the room then the nurse will feel the implementing measurable against the work that has been carried out. This evaluation will be effective if accompanied by good feedback from the head of the room.

Provide feedback on documentation of nursing care performed by managing nurses is very important to improve the quality of nursing services provided. The results showed more than half $(52.38 \%)$ of nurses implementing percieve the head of the room not good in giving feedback on documentation of nursing care has done. Give feedback in the form of reward and punishment against the work done is very important in improving the performance of nursing because nurses will be aware of the short comings and be know how to fix short comings in documenting the nursing care [42]. Therefore, the head of the room can optimize the system of reward and punishment in the room in order to nurses more motivated in documenting of nursing care.

\section{CONCLUSION}

There is a connection with a Chief Compliance supervised nurse in the documentation of the completeness of the records document of nursing care.

\section{ACKNOWLEDGMENT}

There are no sponsors in this research.

\section{REFFERENCE}

[1] N. Natasia, A. Loekqijana, and J. Kurniawati, "Faktor yang Mempengaruhi Kepatuhan Pelaksanaan SOP Asuhan Keperawatan di ICU-ICCU RSUD Gambiran
Kota Kediri," Jurnal Kedokteran Brawijaya, Vol. 28, No. 1, 2014, pp. 21-25.

[2] I. D. Nurseto, N. Sukesi, and Wulandari, "Pengaruh Kepuasan Perawat Terhadap Kelengkapan Dokumentasi Asuhan Keperawatan di Ruang Rawat Inap RSUD Ambarawa," 2014, pp. 1-10.

[3] R. A. Rapar, R. Kundre, V. Kallo, "Hubungan Kepuasaan Kerja Perawat dengan Pelaksanaan Pendokumentasian Keperawatan di Rumah Sakit GMIM Pancaran Kasih Manado,” e-Jurnal Keperawatan (e-Kp), Vol. 6, No. 1, 2018.

[4] D. R. Hidayat, "Ilmu Perilaku Manusia, Pengantar Psikologi untuk Tenaga Kesehatan Medis," Jakarta: Trans Info Media, 2009.

[5] E. D. Purwanti, "Kelengkapan Dokumentasi Asuhan Keperawatan dan Karakteristiknya Pada Pasien Rawat Inap Dewasa Non Kebidanan Di Rumah Sakit Haji Jakarta." Jakarta: Universitas Indonesia, 2012.

[6] M. Nurman, "Faktor - Faktor yang Berhubungan Dengan Pendokumentasian Keperawatan di Ruang Rawat Inap RSUD Bangkinang," Vol. 19, 2013, pp. 113.

[7] I. Utami, "Ketidak Patuhan." Retrieved June 26, 2017, from https://www.scribd.com/document/ 336893143/ketidakpatuhan, 2017.

[8] L. Meivinia, "Ketidakpatuhan," Retrieved from https://www.coursehero.com/file/p23gmup/80-

DEFINISI-Ketidakpatuhan-Tindakan-penghilanganatau-tindakan-kejahatan-oleh/, 2017.

[9] S. Aswar, S. Hamsinah, and A. Kadir, "Faktor yang Mempengaruhi Efektifitas Pelaksanaan Pendokumentasian Asuhan Keperawatan di Instalasi Rawat Inap Bedah Rumah Sakit Umum Daerah Andi Makkasau Parepare," Jurnal Ilmiah Kesehatan Diagnosis, Vol. 5, No. 4, 2014, pp. 460-466.

[10] D. Nuryani, and R. T. S. Hariyati, "Pengetahuan dan Sikap Perawat Terhadap Kelengkapan Pendokumentasian Asuhan Keperawatan di Rumah Sakit H Jakarta," 2014, pp. 1-9.

[11] A. Pribadi, "Analisis Pengaruh Faktor Pengetahuan, Motivasi, dan Persepsi Perawat Tentang Supervisi Kepala Ruang Terhadap Pelaksanaan Dokumentasi Asuhan Keperawatan di Ruang Rawat Inap RSUD Kelet Jepara Provinsi Jawa Tengah," Semarang: Universitas Diponegoro, 2009.

[12] J. Gibson, J. M. Ivancevich, J. H. Donnelly, and R. Konopaske, Organizations: Behavior, Structure, Processes, 14th ed, Boston: McGraw-Hill, 2012.

[13] E. A. Wirawan, D. Novitasari, and F. Wijayanti, "Hubungan Antara Supervisi Kepala Ruang dengan Pendokumentasian Asuhan Keperawatan di Rumah Sakit Umum Daerah Ambarawa," Jurnal Managemen Keperawatan, Vol. 1, No. 1, 2013, pp. 1-6.

[14] S. I. A. Nindyanto, N. Sukesi, and M. A. B. Kusuma, "Pengaruh Supervisi Kepala Ruang Terhadap Dokumentasi Asuhan Keperawatan di Ruang Rawat Inap RSUD Ungaran," 2013, pp. 1-8.

[15] N. Natasia, S. Andarini, and M. Koeswo, "Hubungan antara Faktor Motivasi dan Supervisi dengan Kinerja Perawat dalam Pendokumentasian Discharge Planning di RSUD Gambiran Kota Kediri," Jurnal Aplikasi Manajemen, Vol. 12, No. 4, 2014, pp. 723-730. 
[16] E. Herdiana, and E. M. Rosa, "Pengaruh Fungsi Manajerial Supervisi Klinik Terhadap Dokumentasi Asuhan Keperawatan di RS PKU Muhammadiyah Yogyakarta," 2014, pp. 1-19.

[17] R. I. Yanti, and B. E. Warsito, "Hubungan Karakteristik Perawat, Motivasi, dan Supervisi dengan Kualitas Dokumentasi Proses Asuhan Keperawatan. Jurnal Managemen Keperawatan,” Vol. 1, No. 2, 2013, pp. 107-114.

[18] M. V. H. Rumampuk, Budu, and W. Nontji, "Peran Kepala Ruangan Melakukan Supervisi Perawat Dengan Penerapan Patient Safety di Ruang Rawat Inap Rumah Sakit," 2013, pp. 1-12.

[19] W. Rakhmawati, "Pengawasan dan Pengendalian Dalam Pelayanan Keperawatan (Supervisi, Manajemen Mutu dan Resiko)," In Pelatihan Manajemen Keperawatan, 2009, pp. 11-16.

[20] D. Basuki, "Hubungan Persepsi Perawat Pelaksana Tentang Supervisi Pimpinan Ruang Dengan Pelaksanaan Standar Operasional Prosedur Pemberian Obat Parenteral Intravena di Rumah Sakit Daerah Sidoarjo," Jakarta: Universitas Indonesia, 2012.

[21] N. Utami, M. Saparwati, and Y. Siswanto, "Hubungan Kualitas Supervisi Kepala Ruang Terhadap Kepatuhan Perawat Melakukan Standar Cuci Tangan di Instalasi Rawat Inap RST Dr. Soedjono Magelang," 2016, pp. $2-15$.

[22] Supratman, and A. Sudaryanto, "Model-model Supervisi Keperawatan Klinik," Berita Ilmu Keperawatan, Vol. 1, No. 4, 2008, pp. 193-196.

[23] W. M. Cross, A. G. Moore, T. Sampson, C. Kitch, and C. Ockerby, "Implementing Clinical Supervision for ICU Outreach Nurses: A Case Study of Their Journey," Australian Critical Care, Vol. 25, No. 4, https://doi.org/10.1016/j.aucc.2012.01.004, 2012, pp. 263-270.

[24] A. Kenny, and A. Allenby, "Nurse Education in Practice Implementing Clinical Supervision for Australian Rural Nurses. Nurse Education in Practice," Vol. 13, No. https://doi.org/10.1016/j.nepr.2012.08.009, 2013, pp. $165-169$.

[25] R. Sandra, R. Sabri, and D. Wanda, "Analisis Hubungan Motivasi Perawat Pelaksana dengan Pelaksanaan Pendokumentasian Asuhan Keperawatan di Ruang Rawat Inap RSUD Pariaman," 2012.

[26] A. Triyoga, and P. A. K. Dewi, "Pelaksanaan Dokumentasi Keperawatan di Instalasi Rawat Inap Rumah Sakit Baptis Kediri," Jurnal Penelitian Keperawatan, Vol. 1, No. 2, 2015, pp. 155-164.

[27] Supratman, and Y. W. Utami, "Pendokumentasian Asuhan Keperawatan Ditinjau Dari Beban Kerja Perawat. Ilmu Keperawatan,” Vol. 2, No. 1, 2009, pp. 7-12.

[28] S. Sugiyati, "Hubungan Pengetahuan Perawat Dalam Dokumentasi Keperawatan dengan Pelaksanaannya di Rawat Inap RSI Kendal," In Prosiding Konferensi Nasional II PPNI Jawa Tengah, 2014, pp. 298-307.

[29] T. Prabowo, Dokumentasi Keperawatan, Yogyakarta: Pustaka Baru Press, 2017.
[30] S. Hartati, "Kualitas Dokumentasi Asuhan Keperawatan di Ruang Rawat Inap RS PKU Muhammadiyah Yogyakarta," 2010.

[31] Bara, and Suryati, "Hubungan Motivasi Perawat dengan Pelaksanaan Pendokumentasian Asuhan Keperawatan di Ruang Rawat Inap RSUD Pasar Rebo. Jurnal Health Quality," Vol. 5, No. 1, 2014, pp. 1-66.

[32] C. M. Barbosa, M. F. Z. Mauro, S. A. B. Cristóvão, and J. A. Mangione, "The Importance of Standard Operating Procedures (SOPs) for Clinical Research Centers," Revista Da Associacao Medica Brasileira, Vol. 57, No. 2, https://doi.org/10.1016/S22554823(11)70032-7, 2011, pp. 134-135.

[33] K. Sunde, "SOPs and The Right Hospitals to Improve Outcome After Cardiac Arrest. Best Practice and Research: Clinical Anaesthesiology," Vol. 27, No. 3, https://doi.org/10.1016/j.bpa.2013.07.009, 2013, pp. 373-381.

[34] Martini, "Hubungan Karakteristik Perawat, Sikap, Beban Kerja, Ketersediaan Fasilitas dengan Pendokumentasian Asuhan Keperawatan di Rawat Inap BPRSUD Kota Salatiga," Semarang: Universitas Diponegoro, 2007.

[35] G. Priyadi, Panduan Audit Sistem Mutu, Jakarta: Bumi Aksara, 2012.

[36] V. Wardhani, Manajemen Keselamatan Pasien, Malang: UB Press, 2017.

[37] M. Balki, D. Hoppe, D. Monks, M. E. Cooke, L. Sharples, and R. Windrim, "Multidisciplinary Delphi Development of a Scale to Evaluate Team Function in Obstetric Emergencies: The PETRA Scale," JOGC JUIN, Vol. 39, No. https://doi.org/10.1016/j.jogc.2017.01.030, 2017, pp. 434-442.e2.

[38] Y. R. Lapeña-Moñux, L. Cibanal-Juan, M. L. MaciáSoler, M. I. Orts-Cortés, and A. Pedraz-Marcos, "Interpersonal Relations and Nurses' Job Satisfaction Through Knowledge and Usage of Relational Skills," Applied Nursing Research, Vol. 28, No. 4, https://doi.org/https://doi.org/10.1016/j.apnr.2015.01.0 09, 2015, pp. 257-261.

[39] M. H. Bakri, Manajemen Keperawatan, Konsep dan Aplikasi dalam Praktik Keperawatan Profesional, Yogyakarta: Pustaka Baru Press, 2017.

[40] R. Dewi, K. Yetti, and D. Ayubi, "Supervisi Kepala Ruangan Berdasarkan Kelengkapan Pendokumentasian Auhan Keperawatan," Jurnal Keperawatan Indonesia, Vol. 12, No. 3, 2007.

[41] R. Kwang, and D. Ayuningtyas, "Evaluasi Kinerja Perawat Pelaksana Rumah Sakit M. H. Thamrin Salemba dengan Pendekatan Personal Balance Scorecard Tahun 2010," Jurnal Manajemen Pelayanan Kesehatan, Vol. 14, No. 04, 2011, pp. 197-206.

[42] V. Tetty, and A. Nuryanti, "Pengembangan Instrumen Penilaian Kinerja Asuhan Keperawatan Berbasis Web di Ruang Rawat Inap," Mahakam Nursing Journal, Vol. 2, No. 2, 2017, pp. 62-73. 